\title{
PERAN MANAJER DALAM PENANGGULANGAN KONFLIK ORGANISASI
}

\author{
M. Dhorifin \\ e-mail:mdhorifin@gmail.com \\ Sekolah Tinggi Agama Islam Nahdlotul Ulama' (STAINU) Karangploso Kabupaten Malang
}

\begin{abstract}
The main objective of conflict management behavior is to establish and maintain cooperative working relationship with subordinates, peers, superiors and outsiders. Some forms of conflict management behaviors such as bargaining and integrative problem solving, the approaches to dealing with conflicts involving a manager and others whose assistance they need to achieve work goals. Conflict management as well as efforts to mediate conflicts among others. The main purpose of behavior to build a team is to build a working unit in solidarity with the identification of a strong and a high level of cooperation.
\end{abstract}

Keywords: manager, organizational conflict

\section{Abstrak}

Tujuan utama dari perilaku manajemen konflik adalah untuk membangun dan mempertahankan hubungan kerja yang kooperatif dengan bawahan, rekan-rekan, atasan dan pihak luar. Beberapa bentuk perilaku manajemen konflik seperti tawarmenawar, dan pemecahan masalah integratif, pendekatan untuk menangani konflik yang melibatkan manajer dan orang lain yang bantuannya dibutuhkan untuk mencapai tujuan kerja. Manajemen konflik adalah upaya menyelesaikan masalahmasalah di organisasi pendidikan. Tujuan utama dari perilaku terbuka dan terencana untuk membangun sebuah tim adalah untuk membangun sebuah unit kerja dalam solidaritas dengan identifikasi yang kuat dan kerja sama tingkat tinggi.

Kata kunci: manager, konflik organisasi

\section{Pendahuluan}

Kemajuan suatu organisasi ditentukan oleh para pemimpinnya. Pemimpin berperan selaku motor penggerak dalam kehidupan organisasi. Para pemimpin organisasi dewasa ini menghadapi berbagai tantangan untuk mengimbangi persaingan asing, meningkatkan produktivitas, dan mengambil keputusan yang tepat dalam rangka melayani masyarakat yang multi kompleks.

Masalah-masalah organisasi dibutuhkan pemimpin yang mempunyai kemampuan mengarahkan dan menggerakkan personil melaksanakan program kerja masing-masing. Menggerakkan dimaksudkan kemampuan membujuk orang-orang mencapai tujuantujuan yang telah ditetapkan dengan penuh semangat. Unsur esensial dalam organisasi yaitu kebersamaan langkah maupun gerak didasarkan instruksi yang jelas untuk mencapai tujuan serta mampu menerapkangaya kepemimpinan secara efektif. Menurut Hoy dan Miskel dalam Sagala (20013 : 65), pemimpin yang efektif cenderung mempunyai hubungan dengan bawahan yang sifatnya mendukung (support) dan meningkatkan rasa percaya diri menggunakan kelompok membuat keputusan. Ini berarti kepemimpinan seseorang tidak hanya didasari kekuasaan (power) akan tetapi atas kesadaran bawahan yang menganggap bahwa pekerjaan merupakan bagian dari kebutuhannya.

Untuk mencapai tujuan organisasi, tidak jarang terjadi perbedaan persepsi atau pandangan diantara individu atau 
diantara kelompok individu dalam menterjemahkan misi organisasi sehingga menimbulkan konflik. Pandangan lama menganggap konflik dalam organisasi sebagai suatu hal yang negatif, menjurus pada perpecahan organisasi, untuk itu harus dihilangkan karena menghambat kinerja optimal. Perselisihan dianggap sebagai indikasi adanya sesuatu yang salah dengan organisasi, dan itu berarti aturanaturan organisasi tidak dijalankan. Pandangan lama selalu mengkhawatirkan keberadaan konflik, maka menjadi tugas pimpinan untuk menghindarkan, bahkan bila perlu menghilangkannya sama sekali.

Pada saat ini, sejumlah ahli manajemen beranggapan bahwa konflik di dalam organisasi tidak dapat dihindari dan keberadaannya dapat meningkatkan prestasi kerja sebagai akibat dari kompetisi kelompok. Gibson, Ivancevich, dan Donnelly (1996 : 436) berpendapat bahwa konflik antar individu maupun antar kelompok di dalam organisasi tidak dapat dielakkan, kinerja organisasi yang optimal memerlukan tingkat konflik yang sedang, dan mereka beranggapan bahwa tanpa konflik berarti organisasi tidak ada perubahan. Pendapat yang hampir sama dikemukakan oleh Cummings (1980: 41) bahwa konflik tidak selalu mengganggu, karena sejumlah konflik tertentu diperlukan untuk membentuk kelompok dan memelihara kehidupan kelompok kerja.

Pada dasarnya konflik selalu hadir pada setiap organisasi, baik organisasi kecil maupun organisasi besar, konflik dapat berdampak positif dan negatif terhadap kinerja organisasi, tergantung pada sifat konflik dan pengelolaannya. Dengan demikian tidak ada alasan untuk menghilangkan semua bentuk konflik, kecuali yang menghambat pencapaian tujuan organisasi. Tugas pemimpin adalah mengelola konflik agar dapat bermanfaat guna mendorong perubahan dan inovasi.

\section{Konflik Dalam Organisasi}

1. Konsep Dasar Konflik Menurut Kartini Kartono (1986 : 173) bahwa kata konflik berasal dari kata configere, conflictum yang berarti saling berbenturan. Kemudian arti kata ini ialah semua bentuk benturan, tabrakan, ketidak sesuaian, ketidak serasian, pertentangan, perkelahian, oposisi, dan interaksiinteraksi yang antagonis bertentangan. Stoner (1996 : 229) menyatakan konflik adalah ketidaksepakatan mengenai alokasi sumber daya yang jarang atau pertentangan mengenai sasaran, nilai, persepsi dan sebagainya, dapat terjadi pada tingkat antar pribadi atau organisasi. Terry(1986 : 87) mengemukakan konflik berarti adanya oposisi antara orang-orang, kelompok-kelompok atau organisasiorganisasi.

Sedangkan menurut Hasibuan (2012 :199) konflik merupakan persaingan yang kurang sehat berdasarkan ambisi dan sikap emosional dalam memperoleh kemenangan. Konflik akan menimbulkan ketegangan, konfrontasi, perkelahian, dan frustasi jika tidak dapat diselesaikan. Ernie Trisnawati Sule (2010: 290) menjelaskan konflik adalah adanya kesenjangan atau ketidaksesuaian diantara berbagai pihak dalam suatu organisasi dengan organisasi lain, diantara berbagai bidang dalam sebuah organisasi, maupun diantara anggota didalam suatu bagian tertentu dalam organisasi.

Selanjutnya Clinton F. Fink, dalam kartini kartono (1986: 173) mengatakan bahwa konflik adalah; a) relasi-relasi psikologis yang antagonis, berkaitan dengan tujuan-tujuan yang tidak bisa disesuaikan, interest-interest eksklusif dan tidak bisa dipertemukan, sikap-sikap emosional yang bermusuhan dan strukturstruktur nilai yang berbeda. b) interaksi yang antagonis, mencakup tingkah laku lahiriah yang tampak jelas, mulai dari bentuk-bentuk perlawanan halus, terkontrol, tersembunyi, tidak langsung, sampai pada bentuk perlawanan terbuka, kekerasan, perjuangan tidak terkontrol benturan latent, pemogokan, huru hara, makar, gerilya, perang dan lain-lain.

Uraian diatas, dapat disimpulkan bahwa konflik merupakan suatu pertentangan dan ketidaksesuaian 
kepentingan, tujuan dan kebutuhan dalam situasi formal, sosial dan psikologis, sehingga menjadi antagonis, ambivalen dan emosional. Jadi unsur-unsur yang terkandung dalam konflik itu terdiri dari: a) adanya pertentangan, ketidaksesuaian, perbedaan, b) adanya pihak-pihak yang berkonflik, c) adanya situasi dan proses, dan d) adanya tujuan, kepentingan dan kebutuhan.

Dalam Islam sebagaimana yang diungkapkan Hafifuddin dan Tanjung dalam Siswanto (2008: 177) konflik merupakan perbedaan pendapat yang akan menyebabkan ketidakharmonisan dan pertentangan yang membahayakan antara pihak-pihak yang telibat konflik. Konflik yang terjadi tersebut dapat membahayakan persatuan dan kesatuan. Konflik yang demikian disebut dengan "tanazu". Sebagaimana dinyatakan dalam al-Qur`an surat al-Anfaal ayat 46 sebagai berikut :

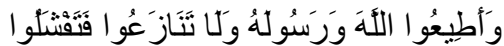

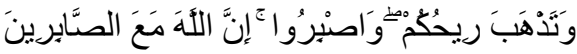

Artinya: Dan taatlah kepada Allah dan Rasul-Nya dan janganlah kamu berbantah-bantahan, yang menyebabkan kamu menjadi gentar dan hilang kekuatanmu dan bersabarlah. Sesungguhnya Allah beserta orang-orang yang sabar. (Q.S. al-Anfaal: 46).

\section{Perkembangan Pandangan Terhadap Konflik}

Terdapat tiga pandangan mengenai konflik yang terjadi dalam organisasi. Robbins dan Judge dalam Wibowo (2013: 220-221) membedakan perkembangan pandangan tersebut dalam tiga kategori, yaitu :

1) The Traditional View of Conflict. Pandangan ini menyatakan bahwa semua konflik adalah menyakitkan dan harus dihindari. Konflik dipandang negatif dan didiskusikan dengan terminologi seperti kekerasan, perusakan, dan tidak rasional.
Konflik bersifat disfungsional sebagai hasil dari buruknya komunikasi, kurangnya keterbukaan dan kepercayaan di antara orang, dan kegagalan manajer merespon pada kebutuhan dan aspirasi pekerja.

2) The Interactionist View of Conflict. Pandangan ini cenderung mendorong terjadinya konflik, konflik tidak hanya merupakan kekuatan positif dalam kelompok, tetapi juga kebutuhan mutlak bagi kelompok untuk berkinerja secara efektif. Menurut pandangan ini tingkat konflik minimal dapat membantu kelompok bergairah, melakukan kritik diri, dan kreatif. Menurut pandangan interactionist tidak semua konflik baik. Functional conflict yang mendukung tujuan kelompok dan memperbaiki kinerja merupakan bentuk konflik yang konstruktif. Sedang konflik yang mengganggu kinerja kelompok bersifat destruktif dan dinamakan dysfunctional conflict.

3) Resulation View of Conflict. Pandangan ini berargumen bahwa konflik merupakan peristiwa yang wajar terjadi dalam semua kelompok dan organisasi. Konflik merupakan sesuatu yang tidak dapat di hindari dan lebih memfokus pada penyelesaian konflik produktif. Pandangan ini menemukan metode konstruktif untuk menyelesaikan konflik secara produktif sehingga pengaruh yang mengganggu dapat diminimalkan.

Selajutnya Sujak dalam Soetopo, (2012: 269) melihat konflik dari dua sudut pandang, yaitu pandangan lama dan pandangan baru. Untuk memahami dua pandangan ini, berikut disajikan dalam tabel. 
Tabel Paradigma Lama dan Paradigma Baru Tentang Konflik

\begin{tabular}{|c|c|}
\hline Pandangan Lama & Pandangan Baru \\
\hline $\begin{array}{l}\text { 1. Konflik harus dihilangkan dari } \\
\text { organisasi, karena dapat } \\
\text { mengganggu organisasi dan } \\
\text { merusak prestasi } \\
\text { 2. Dalam organisasi yang baik tidak } \\
\text { ada konflik } \\
\text { 3. Konflik harus dihindari } \\
\text { 4. Konflik jelek, karena dapat } \\
\text { menjurus ke tingkat stress yang } \\
\text { lebih tinggi, memunculkan } \\
\text { kejahatan dan sabotase terhadap } \\
\text { program } \\
\text { 5. Dengan mengoordinasikan } \\
\text { program secara baik, manajer } \\
\text { akan membentuk perilaku } \\
\text { pegawai sepenuhnya. }\end{array}$ & $\begin{array}{l}\text { 1. Konflik sesungguhnya meningkatkan } \\
\text { prestasi organisasi, maka harus } \\
\text { dikelola dengan baik. } \\
\text { 2. Dalam organisasi yang baik, konflik } \\
\text { yang memuncak mendorong anggota } \\
\text { memacu prestasi } \\
\text { 3. Konflik merupakan bagian integral } \\
\text { dari kehidupan organisasi. } \\
\text { 4. Konflik itu baik karena dapat } \\
\text { merangsang untuk memecahkan } \\
\text { masalah } \\
\text { 5. Banyak faktor yan menentukan } \\
\text { perilaku pegawai dalam } \\
\text { pekerjaannya. Manajer tidak dapat } \\
\text { mengontrol faktor-faktor situasional } \\
\text { dan harus menghadapi kemungkinan } \\
\text { terjadinya konflik. }\end{array}$ \\
\hline
\end{tabular}

\section{Proses Konflik}

Konflik adalah proses yang dinamis. Menurut Robbins (1996: 127) bahwa proses konflik dapat dilihat dari lima tahap yaitu oposisi atau ketidakcocokan potensial, kognisi dan personalisasi, maksud, perilaku, dan hasil. Proses ini didiagramkan sebagai berikut:

Gambar Proses Konflik

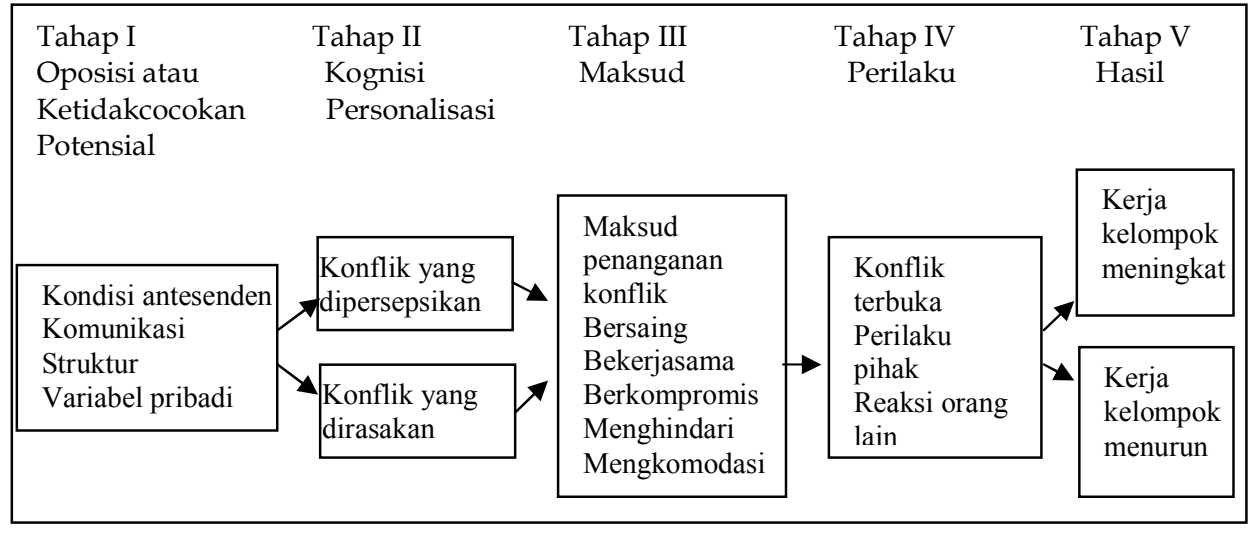




\section{Penyebab Konflik}

Menurut James A. F. Stoner, Charles Winkel dalam J. Winardi (2004 : 437-439) menyatakan bahwa terdapat lima macam tipe konflik yang mungkin terjadi dalam kehidupan keorganisasian, antara lain yaitu:

1. Konflik didalam individu terjadi, apabila seorang individu tidak pasti tentang pekerjaan apa yang diharapkan daripadanya untuk dilaksanakan apabila tuntutantuntutan tertentu dan pekerjaan tersebut berbenturan dengan tuntutan tuntutan lain, atau apabila individu tersebut diekspektasi untuk melakukan hal-hal yang melebihi kemampuannya. Perhatikan gambar :

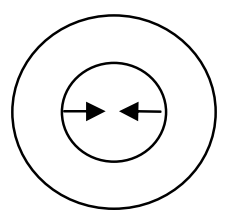

2. Konflik antar individu-individu di dalam organisasi yang sama sering kali terlihat sebagai hal yang timbul karena perbedaanperbedaan dalam kepribadian. Perhatikan gambar berikut :

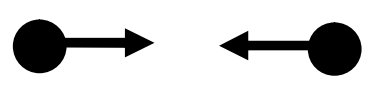

3. Konflik antar individu-individu dan kelompok-kelompok sering kali berhubungan dengan cara para individu menghadapi tekanan akan konformitas, yang dipaksakan terhadap diri mereka oleh kelompok kerja mereka.

4. Konflik antara kelompokkelompok dalam organisasi yang sama merupakan tipe konflik yang paling banyak diperhatikan kita. Apa yang dinamakan konflik-konflik antara garis-staf dan antara manajemen dan pekerja merupakan dua macam bidang konflik yang berkaitan dengan konflik interkelompok.

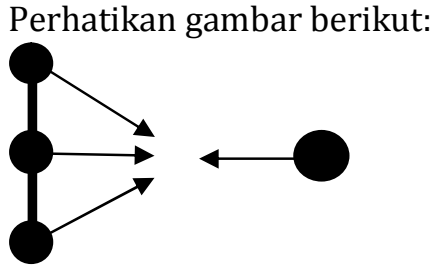

5. Konflik antara organisasiorganisasi di dalam ruang lingkup ekonomi di Amerika Serikat dan banyak negara lain dianggap sebagai sebuah bentuk konflik yang inhern dan yang dikehendaki. Perhatikan gambar berikut:

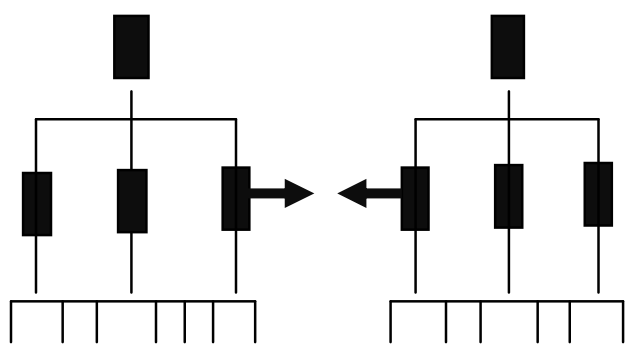

Adapun sebab-sebab terjadinya konflik itu bermacam-macam. Gibson (1989: 236-239) menjelaskan beberapa sebab terjadinya konflik antar kelompok yaitu :

1. Saling ketergantungan (Interdependence). Saling bergantung dalam pekerjaan terjadi jika dua kelompok organisasi atau lebih saling membutuhkan satu sama lain dalam menyelesaikan tugas mereka. Potensi konflik dalam situasi semacam ini cukup tinggi.

Ada tiga macam situasi saling bergantungan diantara kelompok yang perlu diketahui, yaitu:

1) Ketergantungan yang dipusatkan (Pooled independence). Tiap-tiap kelompok kerja sendirisendiri dan tidak memerlukan interaksi antara satu kelompok dengan kelompok 
lainnya. Akan tetapi prestasi organisasi secara keseluruhan akan ditentukan oleh prestasi kelompok-kelompok yang ada.

2) Ketergantungan yang berurutan (Sequetal independence). Penyelesaian tugas oleh kelompok yang satu akan menentukan pelaksanaan tugas oleh kelompok berikutnya.

3) Ketergantungan timbal balik (Reciprocal independence). Situasi dimana keluaran (hasil kerja) dari kelompok yang satu menjadi masukan bagi kelompok yang lain.

2. Perbedaan Tujuan (Differences in Goals). Perbedaan tujuan diantara berbagai kelompok atau unit (satuan) dalam organisasi. Misalnya, unit produksi bertujuan semaksimal mungkin menekan biaya produksi dengan mengusahakan sedikit mungkin produk yang rusak; sementara bagian Penelitian dan pengembangan berurusan dengan pengembangan ide-ide baru untuk mengubah dan mengembangkan produk baru yang berhasil secara komersil. Ini juga bisa menjadi potensi konflik. Perbedaan tujuan dapat disertai dengan persepsi yang berbeda tentang suatu realita, realita itu akan menimbulkan konflik. Hal ini banyak ditemui dalam organisasi.

3. Perbedaan dalam Persepsi (Differences in Perseption). Ada banyak faktor yang menyebabkan kelompok dalam organisasi mempunyai persepsi berbeda-beda, antara lain:

1) Tujuan yang berbeda-beda (Differences Goals)

2) Perbedaan pandangan waktu (Differences time Horizons)

3) Ketidaksamaan status (Status Incongruency)

4) Persepsi yang tidak seksama (Inaccurate Perceptions)
4. Permintaan yang meningkat akan spesialis (The Increased Demand for Specialists).

Selanjutnya Gibson (1989:241-242) menjelaskan bahwa konsekuensi konflik disfungsional antar kelompok dapat dilihat dari perubahan yang terjadi dalam kelompok dan kemudian melihat perubahan yang terjadi diantara kelompok-kelompok.

1. Perubahan di dalam kelompok (Changes Within Groups). Beberapa perubahan yang mungkin terjadi di dalam kelompok yang terlibat dalam konflik di dalam kelompok, anatara lain:

a. Kesatu paduan kelompok yang meningkat (Increased Group Cohesivenes)

b. Bertambahnya kepemimpinan yang autokratis (Rise in Autocratic Leadership)

c. Memusatkan perhatian pada kegiatan (Focus on Activity)

d. Menekankan loyalitas (Emphasis on Loyalty)

2. Perubahan diantara kelompokkelompok (Changes between Groups). Dalam situasi konflik mungkin terjadi perubahan diantara kelompok-kelompok yang terlibat, antara lain:

a. Persepsi yang menyimpang (Distorted Perception)

b. Komunikasi yang menurun (Decreased Communication)

Sedangkan menurut Richard L. Daft (2006: 486-487), beberapa faktor dapat menyebabkan orang-orang terlibat dalam konflik, antara lain :

1. Sumber daya yang langka

2. Ambiguitas yurisdiksional

3. Gangguan komunikasi

4. Bentrokan kepribadian

5. Perbedaan kekuasaan dan status

6. Perbedaan tujuan 
Selanjutnya Alex S. Nitisemito(1996: 126-128) mengemukakan beberapa sebab terjadinya suatu konflik, antara lain yaitu :

1. Perbedaan pendapat

2. Salah paham

3. Salah satu atau kedua pihak merasa dirugikan

4. Perasaan yang terlalu sensitif

Selanjutnya akibat yang ditimbulkan oleh konflik pada dasarnya ada dua, yaitu negatif atau merugikan dan positif atau menguntungkan. Adapun akibat positif dari adnya konflik adalah 1) menimbulkan kemampuan mengoreksi diri sendiri, 2) meningkatkan prestasi, 3) pendekatan yang lebih baik, 4) mengembangkan alternatif yang lebih baik. Adapun akibat yang negatif antara lain sebagai berikut : 1) subyektif dan emosional, 2) apriori, 3) saling menjatuhkan, 4) frustasi.

\section{Gambar Sebab dan Akibat Konflik}

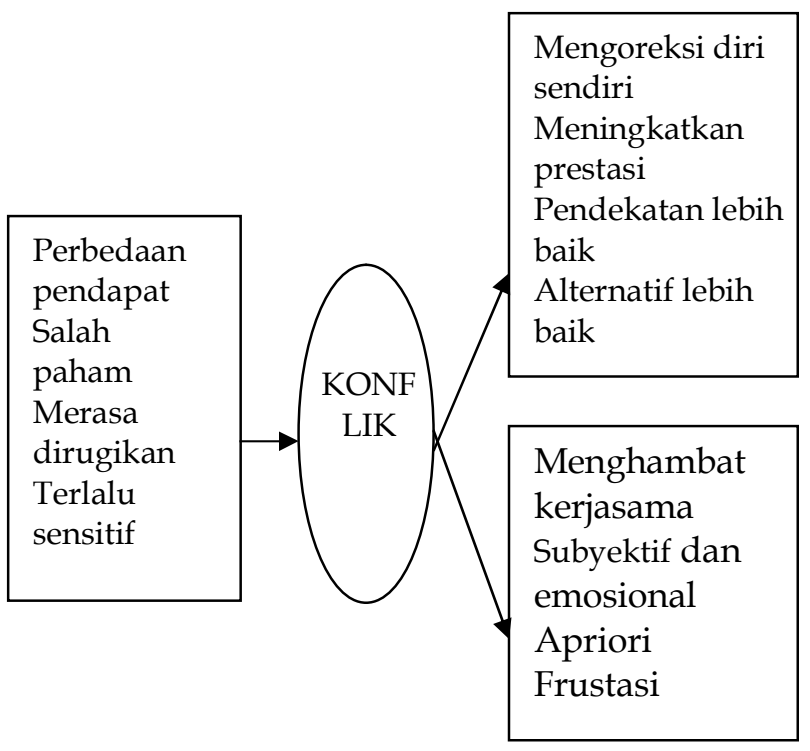

\section{Manajer dan Penanggulangan Konflik Organisasi}

\section{Peran manajer}

Manajer mempunyai peranan yang besar dalam menangani konflk. Disamping mereka juga bisa terlibat konflik dalam organisasi. Manajer dapat berperan sebagai mediator dalam konflik antar pihak. Sebagai mediator manajer harus memiliki keterampilan penganganan konflik yang cukup memadai sehingga dinamika konflik dapat diambil manfaatnya.

SelanjutnyaRobert L. Katz dalam Handoko (2009: 36-37)menjelaskan keterampilan-keterampilan manajerial yang dibutuhkan untuk menjadi seorang manajer yang efektif adalah :

1) Keterampilan konseptual (Conceptual skills), adalah kemampuan mental untuk mengkoordinasikan dan mengintegrasikan seluruh kepentingan dan kegiatan organisasi.

2) Keterampilan kemanusiaan (Human skills), adalahkemampuan untuk bekerja dengan memahami dan memotivasi orang lain, baik sebagai individu ataupun kelompok.

3) Keterampilan administrasi,(Administrative skills),adalahseluruh keterampilan yang berkaitan dengan perencanaan, pengorganisasian, penyususnan kepegawaian dan pengawasan.

4) Keterampilan teknik(Technical skills), adalah kemampuan untuk menggunakan peralatan, prosedur atau teknik dari suatu bidang tertentu.

Menurut Henry Mintzberg dalam Winardi (2004: 22) mengemukakan bahwa ada sepuluh peranan manajerial yang mainkan oleh para manajer, yaitu:

1. Peran antar pribadi, yang meliputi; 1) peranan sebagai tokoh, 2) peranan sebagai pemimpin, dan 3) peranan sebagai penghubung.

2. Peran informasional, yang meliputi; 1) peranan sebagai pihak penerima, 2) peranan sebagai penyebar berita atau informasi, dan 3) peranan sebagai juru bicara.

3. Peran keputusan, yang meliputi; 1) peranan sebagai 
wirausahawan, 2) peranan sebagai pihak yang mengatasi ganguan-gangguan, 3) peranan sebagai pihak yang mengalokasikan sumber-sumber daya, dan 4) peranan sebagai perantara.

2. Metode Penyelesaian Konflik

Konflik dapat diperlakukan dengan jalan memecahkannya. Pemecahan konflik berarti menemukan penyebab konflik dan memecahkannya sedemikian rupa sehinga tidak meninggalkan potensi konflik di masa depan.

Menurut Robbins (Winardi, 2004: 22), ada beberapa pendekatan dengan menghubungkan variabel cooperativeness dari tingkat tidak kooperatif sampai kooperatif, dan variabel assertiveness dari tingkat tidak tegas sampai tegas. Kombinasi pendekatan kedua variabel tersebut dapat dilakukan pilihan penanganan konflik sebagai berikut:

a. Bersaing. Suatu hasrat untuk memuaskan kepentingan seseorang, tidak peduli dampaknya terhadap pihak lain pada konflik itu.

b. Berkolaborasi. Satu situasi dimana pihak-pihak pada suatu konflik masing-masing sangat berkeinginan untuk memuaskan sepenuhnya kepentingan dari semua pihak

c. Menghindar. Hasrat untuk menarik diri dari atau menekan suatu konflik.

d. Mengakomodasi. Kesediaan dari satu pihak dalam suatu konflik untuk mearuh kepentingan lawannya dia atas kepentingannya

e. Berkompromi. Suatu situasi dalam mana tiap pihak pada suatu konflik besrsedia melepaskan sesuatu.

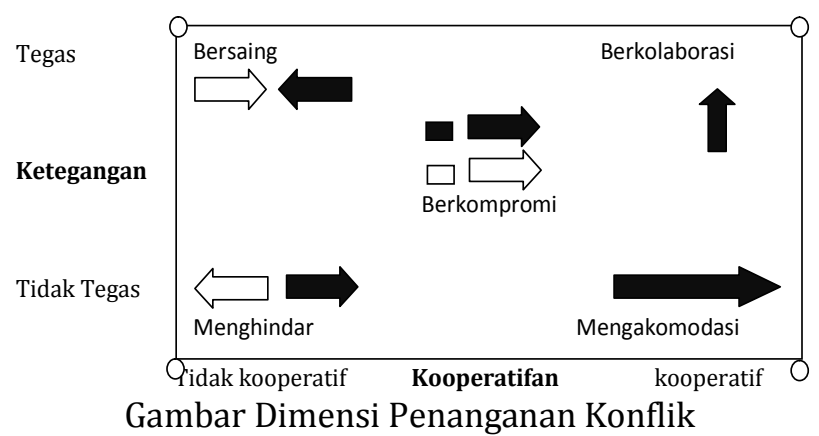

\section{Strategi Manajer dalam Penanggulangan Konflik Organisasi}

Ada beberapa prinsip yang perlu diperhatikan para manajer, organisator, atau pemimpin dalam melaksanakan manajemen konflik, (Soetopo, 2012: 282283) antara lain:

1) Perlakukanlah secara wajar dan alamiah

2) Pandanglah sebagai dinamisator organisasi

3) Media pengujian kepemimpinan

4) Fleksibilitas strategi

Adapun beberapa langkah dan strategi yang perlu dilakukan pemimpin dalam pelaksanaan manajemen konflik, (Soetopo, 2012: 284-285) antara lain:

1) Perencanaan analisis konflik. Hal ini dimaksudkan untuk mendefinisikan atau menentukan konflik apa yang timbul dalam penyelenggaraan satuan pendidikan. Pemimpin pendidikan pada langkah ini harus dapat menentukan sumber penyebabnya, faktor-faktor yang mempengaruhinya, jenisjenisnya, dan keterlibatan pihakpihak yang berkonflik. Apabila hal tersebut semuanya jelas, akhirnya konflik yang sesungguhnya dapat dirumuskan secara jelas dan tegas.

2) Evaluasi konflik. Adalah suatu upaya untuk menentukan kualitas suatu konflik yang telah dirumuskan. Kualitas suatu konflik dapat ditinjau dari dua segi yaitu intensitas dan 
keluasannya. Dengan demikian sebagai manajer konflik perlu melakukan pemecahan konflik sesuai dan berdasarkan skala prioritas tersebut.

3) Pemilihan strategi manajemen konflik. Apabila konflik yang ada sudah jelas maka akan memudahkan manajer dalam memilih strategi manajemen konflik secara tepat. Beberapa pedoman yang perlu di perhatikan manajer dalam memilih strategi manajemen konflik, antara lain; a)Pahamilah beberapa prinsip dalam pelaksanaan manajemen konflik, b)Berdasarkan prinsip-prinsip diatas, pilihlah di antara strategi manajemen konflik yang disarankan, c)Laksanakan strategi manajemen konflik yang dipilih, d)Evaluasilah pelaksanaan strategi manajemen konflik yang dipilih tersebut untuk mengetahui keberhasilan-nya, dan e)Strategi yang telah dipilih dapat dipertahankan bila menunjukkan hasil yang baik, tetapi bila hasilnya tidak atau kurang baik maka perlu dipilihkan strategi lain secara berkelanjutan.

James Cribbin (Hamzah, 1984: 221227) menjelaskan untuk mencegah konflik, maka manajer harus menggunakan dua spektrum strategi untuk mengatasinya, yaitu :

1. Strategi yang paling tidak efektif. Bahwa ada beberapa strategi populer seolah-olah menyelesaikan konflik, tetapi sebetulnya tidak memecahkannya karena memberikan hasil jangka pendek dan menimbulkan kekecewaan, kecurigaan, dan suatu perasaan bahwa perlakuan secara tidak adil. Hal tersebut meliputi: a)paksaan, b)penundaan, c)bujukan, d)koalisi, e)tawar menawar distribusi, f)koeksistensi damai, g)naik banding, h)mediasi, i)pengantaraan, dan j)Persaingan konstruktif.

2. Strategi yang paling efektif. Bahwa strategi yang betul-betul efektif mengendalikan persoalan sekarang sambil meletakkan dasar untuk peningkatan kerjasama suatu kelompok. Kegiatan ini meliputi: a)Tujuan sekutu besar, b) Tawar menawar integratif, c)Campur dan cocokkan.

Menurut Yukl (Udaya, 1998 : 117120) ada beberapa pedoman dalam melakukan strategi tawar menawar dalam penyelesaian konflik, antara lain :

1. Buatlah tawaran awal dengan banyak persyaratan namun tidak kasar

2. Dorong suatu kompromi tanpa terlihat lemah

3. Gunakan persuasi rasional untuk memperkokoh posisi anda

4. Jangan serakah

5. Bantu orang lain tersebut untuk menyelamatkan mukanya.

Kemudian beberapa pedoman dalam melakukan strategi pemecahan masalah yang integratif (kerjasama) yaitu :

1. Membangun rasa saling percaya

2. Identifikasi sasaran-sasaran dan kepercayaan-kepercayaan bersama

3. Identifikasi alasan-alasan yang spesifik dari konflik tersebut

4. Pertimbangkan sederetan pemecahan yang dapat diterima

5. Cobalah cari suatu pemecahan yang optimal

Selanjutnya pedoman dalam menangani konflik diantara orang lain, ada beberapa prosedur yang dikembangkan untuk memudahkan usaha-usaha pihak ketiga untuk menengahi konflik diantara kelompok-kelompok atau antara para individu, yaitu :

1. Tindakan-tindakan yang berorientasi pada masalah yang 
dibuat untuk memudahkan penemuan suatu pemecahan yang segera memuaskan semua pihak terhadap masalah, antara lain :

1) Mendorong agar dibuat definisi yang diterima bersama mengenai masalah tersebut dengan menanyakan bagaimana masalah tersebut harus dilihat, dengan menggunakan istilah-istilah situasional dan bukannya istlah pribadi yang menunjukkan kesalahan

2) Berilah informasi faktual yang relevan dengan masalah tersebut atau membantu membuktikannya

3) Dorong agar tiap pihak memperlihatkan kebutuhan dan prioritas mereka yang sebenarnya

4) Mendorong agar pihak-pihak tersebut mengidentifikasi sasaran-sasaran dan nilai-nilai yang dirasakan bersama

5) Mendorong menciptakan pemecahan integratif setelah masalah tersebut didefinisikan

6) Sarankan kompromikompromi yang membantu atau pemecahan yang integratif yang tidak jelas bagi pihak-pihak tersebut

7) Periksa untuk memastikan komitmen terhadap persetujuan apa saja dari kedua belah pihak

2. Tindakan-tindakan yang berorientasi pada hubungan yang dibuat untuk memperbaiki hubungan antara pihak-pihak yang bertikai, antara lain :

1) Tidak memihak dan perlihatkan penerimaan serta hormat kepada kedua belah pihak

2) Jangan mendorong perilaku yang tidak produktif seperti ancaman, stereotyping, dan membesarbesarkan

3) Pastikan bahwa semua orang mempunyai peluang yang cukup untuk berbicara dan tidak ada orang yang mendominasi pembicaraan

4) Dorong mereka untuk mendengarkan secara aktif

5) Gunakan humor bila sesuai untuk mengurangi ketegangan

6) Gunakan proses prosedur konsultasi untuk mengidentifikasi sumbersumber konflik antarpribadi dan carikan pemecahannya.

Sedangkan menurut Veithzal Rivai (2010:754-755), mengemukakan beberapa pendekatan yang dapat digunakan sebagai kontribusi peran kepemimpinan dalam mengendalikan atau menyelesaikan konflik, antara lain sebagai berikut :

1. Sanggup menyampaikan pokok masalah penyebab timbulnya konflik. Konflik tidak dapat di selesaikan jika permasalahan pokoknya terisolasi. Konflik sangat bergantung pada konteks dan setiap pihak yang terkait seharusnya memahami konteks tersebut. Permasalahan menjadi jelas tidak berdasarkan asumsi, melainkan jika disampaikan dalam pernyataan pasti.

2. Mau mengakui adanya konflik. Pendekatan dengan konfrontasi dalam menyelesaikan konflik biasanya justru mengarahkan untuk membentuk kubu. Untuk itu, bicarakan pokok permasalahan, bukan siapa yang menjadi penyebabnya.

3. Bersedia melatih diri untuk mendengarkan dan mempelajari perbedaan. Pada umumnya kemauan mendengarkan sesuatu dibarengi dengan keinginan untuk memberi tanggapan. Seharusnya kedua belah pihak berusaha untuk benar-benar saling mendengarkan. 
4. Sanggup mengajukan usul atau nasihat. Ajukan usul baru yang didasari oleh tujuan kedua belah pihak dan dapat mengakomodasi keduanya. Tawarkan juga kesediaan untuk selalu dapat membantu perwujudan rencanarencana tersebut.

5. Minimalisir ketidakcocokan. Cari jalan tengah diantara kedua belah pihak yang sering berbeda pandangan dan pendapat. Fokuslah pada persamaan dengan mempertimbangkan perbedaan yang sifatnya tidak mendasar.

\section{Kesimpulan}

Tujuan utama perilaku manajemen konflik adalah untuk membangun dan mempertahankan hubungan kerjasama yang kooperatif dengan para bawahan, teman sejawat, atasan dan pihak luar. Beberapa bentuk perilaku manajemen konflik seperti tawar menawar, dan pemecahan masalah secara integratif, merupakan pendekatan-pendekatan untuk menangani konflik yang menyangkut seorang manajer dan pihak lain yang bantuannya dibutuhkan untuk mencapai sasaran pekerjaan. Manajemen konflik termasuk juga usaha-usaha untuk menengahi konflik diantara orang lain. Tujuan utama perilaku membangun tim adalah untuk membangun sebuah unit kerja yang solider dengan identifikasi anggota yang kuat dan suatu tingkat kerjasama yang tinggi.

\section{Daftar Pustaka}

Cummings, P. W. 1980. Open Management: Guides to Successful Practice. New York: Amacom.

Cribbin, James J. 1981. LeadershipStrategies for Organizational Effectiveness. Amacom, 135 Wett 50th Street, New York, N. Y. Terjemahan Indonesia oleh $\mathrm{Ny}$. Rochmulyati Hamzah, 1984. Kepemimpinan-Strategi

Mengefektifkan Organisasi. Jakarta:
PT Pustaka Binaman Pressindo. Cet. Kedua

Daft, Richard L. 2003. Management, 6th ed, by Cengage Learning Asia Pte Ltd. 5 Shenton Way, \#01-01 UIC Building, Singapore. Terjemahan Indonesia oleh Edward Tanujaya dan Shirly Tiolina. 2006. Manajemen, Edisi 5. Jakarta: Salemba Empat. Jilid. 2.

Gibson, James L. John M. Ivancevich, dan James H. Donnelly Jr. 1982. Organizations 4th edition. Business Publications, Inc. Terjemahan Indonesia oleh Djoerban Wahid. 1989. Organisasi dan Manajemen Perilaku Struktur Proses, Jakarta: Erlangga, Cet. Kelima.

Gibson, J.L., Invancevich, J.M. dan Donnelly, Jr. J.H. 1996. Organisasi: Perilaku, Struktur dan Proses. edisi kedelapan. Alih Bahasa Nunuk Ardiani. Jakarta: Binarupa Aksara.

Handoko, T. Hani. 2009. Manajemen Edisi Kedua. Yogyakarta: BPFE, Cet. Kedua puluh.

Hasibuan, Malayu S.P. 2012. Manajemen Sumber Daya Manusia. Jakarta: Bumi Aksara. Cet. Keenambelas.

Hatta, Ahmad. 2009. Tafsir Al-Qur'An Perkata Dilengkapi Dengan Asbabun Nuzul \& Terjemah. Jakarta: Maghfirah Pustaka.

Kartono, Kartini. 1986. Pemimpin dan Kepemimpinan; Apakah Pemimpin Abnormal itu?. Jakarta: Rajawali. Cet. Ketiga.

Nitisemito, Alex S. 1996. Manajemen Personalia: Manajemen Sumber Daya Manusia. Jakarta: Ghalia Indonesia.

Rivai, Veithzal dan Sylviana Murni. 2010. Educational Management; Analisis Teori dan Praktik. Jakarta: RajaGrafindo Persada, Cet. Ke-2.

Robbins, Stephen P. 1996. Organizational Behaviour. Concepts, Controversies, Applications. Seventh Edition. Prentice Hall, Inc, Englewood Cliffs, New Jerey. Terjemahan Indonesia 
oleh Hadyana Pujaatmaka. 1996. Perilaku Organisasi: Konsep, Kontroversi, Aplikasi. Jakarta: Prenhallindo.

Sagala, Syaiful. 20113. Kemampuan Profesional Guru Dan Tenaga Kependidikan. Bandung: Alfabeta, Cet. Ke-4.

Siswanto \& Sucipto, Agus. 2008. Teori \& Perilaku Organisasi Sebuah Tinjauan Integratif. Malang: UIN-Malang Press.

Soetopo, Hendyat. 2012. Perilaku Organisasi; Teori dan Praktik Dalam Bidang Pendidikan. Bandung: Remaja Rosdakarya, Cet. Kedua.

Stoner, James A.F.., R. Edward Freeman., dan Daniel R. Gilbert Jr. 1996. Management. Englewood Cliffs, New Jersey, Prentice-Hall, Inc. Terjemahan Indonesia oleh Alexander Sindoro. 1996. Manajemen, Jakarta: Prenhalindo.

Terry, R George. 1977. Principles of Management Eighth Edition. Richard D. Irwin, Inc. Terjemahan Indonesia oleh Winardi. 1986. Asas-asas Manajemen Edisi Kedelapan, Bandung: Alumni, Cet. IV.

Trisnawati, Ernie Sule \& Kurniawan Saefullah. 2010. Pengantar Manajemen. Jakarta: Kencana, Cet. Ke-5.

Wibowo. 2013. Perilaku Dalam Organisasi. Jakarta: PT. RajaGrafindo Persada. Cet. Ke-1.

Winardi, J. 2004. Manajemen Perlaku Organisasi. Jakarta: Kencana

Yukl, Gary A. Leadership In Organizations Third Edition. 1994. Prentice-Hall. Inc. Englewood Cliffs, New Jersey. Terjemahan Indonesia oleh Yusuf Udaya. 1998. Kepemimpinan Dalam Organisasi. Jakarta: Prenhallindo 